\title{
CONCISE
}

PUBLICATIONS

\section{Free DNA in Serum and Plasma from Normal Adults}

\author{
Charles R. Stennman \\ From the Department of Medicine, Mt. Sinai School of Medicine of the City \\ University of New York, New York 10029
}

\begin{abstract}
A в S TRACT Circulating DNA has been associated with several human disorders, including the nephritis of systemic lupus erythematosus (SLE), in which it is thought to play an etiological role. However, it remains unclear whether its appearance in the circulation is truly pathological. Several reports, each generally based on a single assay method, have disagreed as to whether DNA may circulate in normals. Some, but not all, of this disagreement may be explained by the recently described appearance of DNA in serum, but not plasma, apparently as the result of release from leukocytes in vitro.

In the present report an attempt is made to clarify this problem. Normal plasma and serum samples were examined by four assays for DNA that were newly modified to enhance their specificity and/or sensitivity. Plasma DNA was undetectable by all four methods, the most sensitive of which could detect $0.05 \mu \mathrm{g} / \mathrm{ml}$ of native DNA (nDNA) or $0.1 \mu \mathrm{g} / \mathrm{ml}$ of single-stranded DNA (ssDNA). Serum DNA was present in 14 of 16 samples tested in variable concentrations with an estimated mean of $1.9 \mu \mathrm{g} / \mathrm{ml}$. It is concluded that the appearance of DNA in adult human plasma is a pathological event. Presumably, previous reports describing detection of DNA in normal plasma were based on the measurement of non-DNAase-sensitive interfering substances. Furthermore, it is emphasized that the use of serum in studies dependent on sensitive assays for DNA (or anti-DNA antibody) introduces an ambiguity that may be avoided by substitution of carefully collected plasma for serum.
\end{abstract}

Received for publication 29 October 1974 and in revised form 21 April 1975.

\section{INTRODUCTION}

Circulating DNA has assumed clinical importance because of its association with several human disorders $(1,2)$ and in particular with the immune complex nephritis accompanying systemic lupus erythematosus $(\mathrm{SLE})^{1}$ in which, in combination with anti-DNA antibody, it appears to play an etiologic role (1). In addition, recent reports have suggested that anti-DNA antibody might be found not only in SLE, but also in patients with other collagen diseases (3), as well as in normals (4). Hence, it seems imperative to clearly establish whether free DNA may be found in the normal circulation, or whether it appears only in conjunction with pathological states. Surprisingly, the literature is conflicting on this point, the majority of reports claiming to have identified such DNA in normals (5-8), but with a number of dissents $(1,2,9)$. The recently described release of DNA into serum during clotting may help in part to clarify the problem (2). However, even studies confined to normal plasma have been in disagreement, with mean DNA concentrations reported from as low as 0 (2) to as high as $35.2 \mu \mathrm{g} / \mathrm{ml}$ (5). Since, in general, each report is based on use of a single assay technique, interpretation is difficult. In addition, in a complex mixture such as plasma, the amount of material interfering with colorimetric assays is likely to be high, relative to the concentration of DNA reportedly found, further compounding the difficulty.

\footnotetext{
1 Abbreviations used in this paper: CIE, counterimmunoelectrophoresis; DPA, diphenylamine; EB, ethidium bromide; nDNA, native DNA; PCA, perchloric acid; SLE, systemic lupus erythematosus; ssDNA, denatured (single stranded) DNA.
} 
The purpose of this study is to attempt reconciliation of these reports by use of four different DNA assays, based on independent principles, to examine normal human plasma and serum. The assays selected have all been either newly devised or modified to increase their specificity and/or sensitivity over those previously used for this purpose.

\section{METHODS}

Blood was obtained atraumatically from normal adults and either anticoagulated with EDTA or allowed to clot and retract completely in glass test tubes. Plasma or serum, after removal of the clot, was separated within $6 \mathrm{~h}$ of collection, after centrifugation at $2,000 \mathrm{rpm}$ for $30 \mathrm{~min}$. Storage at $-20^{\circ} \mathrm{C}$ for up to $2 \mathrm{yr}$ had no demonstrable effect on detectability of DNA in positive specimens by counterimmunoelectrophoresis (CIE), performed as described below. Standards were prepared from calf thymus DNA obtained from Worthington Biochemical Corp., Freehold, N. J., or from human liver DNA prepared by Marmur's method (10). Quantitation of stock solutions was achieved by either the diphenylamine method (11) or by measuring the optical density at $260 \mathrm{~nm}$ and assuming an absorbency of 20 at $1 \mathrm{mg} / \mathrm{ml}$. Deoxyribonuclease I (DNAase), electrophoretically purified, was obtained from Sigma Chemical Co., St. Louis, Mo. Data were analyzed by standard statistical methods (12).

Diphenylamine assay $(D P A)$. The procedure of Giles and Myers (11) was modified to allow measurement of the material rendered acid-soluble by treatment with DNAase. Duplicate 1-ml samples of plasma were incubated for $15 \mathrm{~min}$ at $37^{\circ} \mathrm{C}$ in the presence of $0.02 \mathrm{M} \mathrm{MgCl}$ after the addition of either DNAase $(200 \mu \mathrm{g} / \mathrm{ml})$ or an equal volume of buffer alone. They were then made $0.5 \mathrm{M}$ in $\mathrm{NaClO}_{4}$ and the same amount of DNAase or buffer was again added, followed by incubation for an additional $30 \mathrm{~min}$. Each sample was then precipitated at $4^{\circ} \mathrm{C}$ with $10 \%$ trichloracetic acid (TCA), washed, redissolved in $6 \mathrm{M} \mathrm{NaOH}$ at $20^{\circ} \mathrm{C}$, neutralized with $\mathrm{HCl}$, and reprecipitated with TCA at $4^{\circ} \mathrm{C}$. Each precipitate was extracted with $1 \mathrm{ml}$ of $10 \%$ perchloric acid (PCA) at $70^{\circ} \mathrm{C}$ for 20 min. A 0.5 $\mathrm{ml}$ aliquot of this extract was then used for the deoxyribose assay, as described previously (11). The optical density at $595 \mathrm{~nm}$ was corrected for turbidity by subtracting the reading at $700 \mathrm{~nm}$. Two sets of standards were routinely included, one in $10 \% \mathrm{PCA}$ and the other in normal plasma treated as above. The standard curve for plasma DNA was linear below $200 \mu \mathrm{g} / \mathrm{ml}$. The plasma DNAase treatment was adequate to solubilize more than $90 \%$ of the DNA present in crude lysates of both Micrococcus lysodeikticus and of human leukocytes as determined by the DPA and hybridization assays (vide infra), respectively.

Ethidium bromide $(E B)$ assay. A method employing enhancement of fluorescence of $E B$ when bound to native (n)DNA was followed as described (6), including RNAase pretreatment, except that for each sample an individual blank was prepared by treatment with DNAase $(100 \mu \mathrm{g} /$ $\mathrm{ml}$ ) in the presence of $0.02 \mathrm{M} \mathrm{MgCl}_{2}$ at $37^{\circ} \mathrm{C}$ for $1 \mathrm{~h}$. The test samples were treated similarly except that DNAase was replaced by buffer.

Fluorescence intensity was measured in arbitrary units on an Aminco-Bowman spectrofluorometer (American Instrument Co., Inc., Silver Spring, Md.) with the excitation and emission wavelengths set at $564 \mathrm{~nm}$ and $590 \mathrm{~nm}$, respectively. DNAase-sensitive fluorescence varied linearly below $100 \mu \mathrm{g} / \mathrm{ml}$ of DNA in plasma standards.

CIE. The procedure described by Davis and Davis (2) was followed, except that each sample was made $1 \mathrm{M}$ in $\mathrm{NaCl}$ immediately before assay. This served to increase the sensitivity of the method for nDNA by $50-100$-fold. Antisera obtained from three different patients with SLE and demonstrating antibody by CIE to both native and denatured calf thymus DNA, but not to RNA, were used either undiluted or diluted $1: 1$ with phosphate-buffered saline. Although the data reported were all obtained with a single antiserum (Crisp), the other two yielded similar results on smaller numbers of samples. Antisera and plasma and serum samples (including positive controls) were routinely heated at $56^{\circ} \mathrm{C}$ for $30 \mathrm{~min}$ before use. Positive controls consisted of nDNA added to normal plasma in concentrations of 0.05 and $0.10 \mu \mathrm{g} / \mathrm{ml}$. Positive results were defined as reproducible, sharp lines of precipitate visible without staining at room temperature within $3 \mathrm{~h}$ of electrophoresis. In all cases these lines were abolished by DNAase pretreatment and did not appear with antiserum previously absorbed with nDNA. Each sample was run undiluted and diluted 1:30 with $1 \mathrm{M} \mathrm{NaCl}$ containing $0.01 \mathrm{M}$ potassium phosphate, $\mathrm{pH}$ 7.0. In this way concentrations of nDNA between 0.05 and $150 \mu \mathrm{g} / \mathrm{ml}$ and of ssDNA between 0.2 and $15 \mu \mathrm{g} / \mathrm{ml}$ were routinely demonstrable in plasma. Often as little as $0.02 \mu \mathrm{g} / \mathrm{ml}$ of $\mathrm{nDNA}$ could be detected. To determine titers, serial twofold dilutions in saline-phosphate buffer were tested by CIE after addition of $1 \mathrm{M}$ saline.

RNA-DNA hybridization. This method depends on the ability of enzymatically prepared, tritium-labeled RNA to combine with DNA containing a complementary nucleotide base sequence to form hybrid RNA-DNA molecules that are ribonuclease-resistant. The ability of this assay to distinguish between human and microbial DNA allows use of the latter as carrier in isolating trace amounts of the former from plasma or serum samples (13).

Duplicate 1-ml plasma samples were treated as before with DNAase or buffer, after which the reaction was terminated by making each sample $2.5 \%$ in sodium dodecylsulfate and $0.01 \mathrm{M}$ in EDTA and then treating it with self-digested pronase, $200 \mu \mathrm{g} / \mathrm{ml}$, at $60^{\circ} \mathrm{C}$ for $60 \mathrm{~min}$. Next, $0.1 \mathrm{vol}$ of $1 \mathrm{M}$ Tris, $\mathrm{pH} 9.0$, was added, followed by 0.45 mg DNA from Clostridium perfringens. Each sample was extracted twice with phenol and then twice with ether. DNA was recovered after precipitation with 2 vol of ethanol at $-20^{\circ} \mathrm{C}$. Hybridization reactions were carried out in triplicate in sealed $1-\mathrm{ml}$ glass ampoules containing, in $0.130 \mathrm{ml}, 1.2 \mathrm{M} \mathrm{NaCl}, 10 \%$ formamide, $0.08 \mathrm{M}$ sodium citrate, $0.5 \%$ sodium dodecylsulfate, $10 \mu \mathrm{g}$ DNA, and $300,-$ $000 \mathrm{cpm}$ of complementary human RNA. The latter was prepared with RNA polymerase, with human DNA as template and tritium-labeled uridine $5^{\prime}$ triphosphate (10-20 $\mathrm{Ci} / \mathrm{mM}$ ) obtained from Schwarz/Mann Div., Becton, Dickinson \& Co., Orangeburg, N. Y. The ampoules were heated to $100^{\circ} \mathrm{C}$ for $10 \mathrm{~min}$ and then incubated at $67^{\circ} \mathrm{C}$ for $16-20 \mathrm{~h}$, after which ribonuclease-resistant, hybridized RNA was detected, as previously described (14), by its ability to bind to a nitrocellulose filter. The amount of DNAase-sensitive hybridized RNA varied logarithmically (below $1 \mu \mathrm{g} / \mathrm{ml}$ ) with the concentration of human DNA added to DNA-free, normal plasma.

\section{RESULTS}

Data from the DPA, EB, and hybridization assays on plasma are summarized in Table I. In no case are the 
TABLE I

Detection of DNA in Normal Plasma

\begin{tabular}{lccccc}
\hline \multicolumn{1}{c}{ Method } & $n$ & Treated & Untreated & Difference* & $\begin{array}{c}\text { Minimum detectable } \\
\text { nDNA concentrationf }\end{array}$ \\
\hline DPA, mean $10^{3} \times$ OD $595-700$ & 27 & 17.8 & 18.5 & $0.7 \pm 2.2$ & $10(2.8 \pm 9.9)$ \\
EB, mean arbitrary fluorescence & 16 & 61.0 & 61.6 & $0.6 \pm 0.4$ & $5(6.5 \pm 1.4)$ \\
Hybrid, mean cpm bound to filter & 16 & 16.0 & 17.6 & $1.6 \pm 1.0$ & $0.1(9.2 \pm 2.9)$ \\
CIE, \% positive & 24 & 0 & 4.2 & NA§ & 0.05 \\
\hline
\end{tabular}

* Each figure represents the mean difference between paired DNAase-treated and untreated samples along with the SE. In no case is this figure significantly different from zero $(P>0.1)$.

$\ddagger$ Figure in parentheses represents difference between DNAase-treated and untreated standards containing the minimum detectable amount of DNA as indicated for each assay.

$\S$ Not applicable.

differences between the DNAase-treated and untreated paired samples significant. If, in the EB assay, the DNAase-treated blank is replaced by one consisting of plasma lacking EB and the resulting difference in fluorescence converted to "apparent DNA" by reference to a standard curve, a mean of $17.5 \mu \mathrm{g} / \mathrm{ml}$ is found. This compares with $13.9 \mu \mathrm{g} / \mathrm{ml}$ reported by $\mathrm{Kamm}$ and Smith (6) using this type of blank and presumably results from enhancement of the fluorescence of EB by non-DNAase- and non-RNAase sensitive materials. The fluorescence of the same amount of EB added to buffer alone was found to account for less than $10 \%$ of the difference.

In the hybridization assay, negative controls containing carrier DNA added directly to the assay mixture without having been re-isolated from plasma gave results indistinguishable from those derived from the DNAase-treated plasma samples. This result further confirms the efficacy of the DNAase treatment, as it is inconsistent with the presence of significant amounts of DNAase-resistant DNA in plasma in a form detectable by hybridization.

Only one of the 24 normal plasma samples demonstrated a faint line of precipitation by CIE. Pretreatment of the samples with pronase, $1 \mathrm{mg} / \mathrm{ml}$ at $60^{\circ} \mathrm{C}$ for $1 \mathrm{~h}$, did not result in detection of DNA in any additional samples.

$D N A$ in serum. Examination of 15 normal sera by DPA and 5 by EB failed to demonstrate DNAase-sensitive material, as shown in Table II. However, 14 of 16 unequivocally demonstrated the presence of DNA by CIE. The geometric mean titer was $1: 47.3$ in the positive specimens, with a range between $1: 2$ and $1: 128$. If $0.05 \mu \mathrm{g} / \mathrm{ml}$ is the minimum detectable concentration, the mean for all 16 samples was approximately $1.9 \mu \mathrm{g} / \mathrm{ml}$, an amount not detectable by the DPA or EB methods. The coefficient of variation of the DNA concentration in a group of individually separated samples from an individual venipuncture was the same $(133 \%)$ as in the entire group of sera $(129 \%)$.
To confirm these results, nine sera, positive by CIE, were selected for examination by hybridization. All nine demonstrated greater hybridization than did their paired DNAase-treated controls, a result highly significant by chi square analysis with the sign test $(P<0.004)(12)$. (Similar application of this test to the data on normal plasma showed no significant differences resulting from DNAase treatment in any of the assays). The DNAaseresistant hybridization had a mean \pm SEM of $14.1 \pm 9.3$ $\mathrm{cpm}$ and a range of $1.1-74.0 \mathrm{cpm}$. Thus the wide variability in the previously noted amount of serum DNA was also confirmed by hybridization (coefficient of variation $=66 \%$ ).

\section{DISCUSSION}

The results obtained in this study with the EB assay, as well as previously published data on the DPA method (9), suggest that reports of finding DNA in plasma, at least by these methods, resulted from measurement of interfering substances rather than of true DNA. Except for the use of DNAase-treated, paired controls, the validity of which was demonstrated above, the four assays used in the present study are based on independent principles and therefore complement each other. Thus, although the possibility cannot be ruled out that DNA is present in normal plasma in an unusual form that eludes detection by all four methods, this appears un-

TABLE II

Detection of DNA in Normal Serum

\begin{tabular}{lccccc}
\hline \multicolumn{1}{c}{ Method } & & $\begin{array}{c}\text { DNAase- } \\
\text { treated }\end{array}$ & $\begin{array}{c}\text { Un- } \\
\text { treated }\end{array}$ & Difference* \\
\hline $\begin{array}{l}\text { DPA, mean } 10^{3} \times O D_{595-700} \\
\text { EB, mean arbitrary }\end{array}$ & 15 & 21.0 & 20.8 & $0.2 \pm 3.87$ \\
$\quad$ fluorescence & 5 & 77.0 & 77.4 & $0.4 \pm 0.25$
\end{tabular}

* Each figure represents the mean difference between paired DNAase-treated and untreated samples along with the SE. In no case is this figure significantly different from zero $(P>0.1)$. 
likely. Rather, in accord with several previous studies, as noted above, their agreement in not finding DNA would seem to imply its absence as defined by the limits of sensitivity noted $(0.05 \mu \mathrm{g} / \mathrm{ml}$ for CIE). Thus, it can be concluded that the presence of free $\mathrm{nDNA}$ in amounts greater than this (and of ssDNA in amounts greater than $0.1 \mu \mathrm{g} / \mathrm{ml}$, as detectable by hybridization) in plasma is pathological.

The previously reported erratic occurrance of DNA in serum was confirmed in this study (2). Although of little relevance to previous work demonstrating circulating DNA with comparatively insensitive techniques such as Ouchterlony analysis $(1,15)$, this apparent artifact may lead to confusion when more sensitive assays are utilized. Thus studies dependent on the identification of small concentrations of DNA, for example, as in the reported demonstration in SLE of DNA-antiDNA immune complexes (16), would more securely reflect the in vivo state if performed on atraumatically collected plasma than on serum. Similarly, measurements of anti-nDNA antibody by the sensitive Farr technique (17) might potentially be interfered with unpredictably by this phenomenon and might more reliably be performed on plasma.

\section{ACKNOWLEDGMENTS}

The technical assistance of Irene Wilbur and Santas Tan is gratefully acknowledged.

This investigation was supported in part by grant AM15544 from the U. S. Public Health Service and by a grant from the New York Lupus Erythematosus Foundation.

\section{REFERENCES}

1. Tan, E. M., P. H. Schur, R. I. Carr, and H. G. Kunkel. 1966. Deoxyribonucleic acid (DNA) and antibodies to DNA in the serum of patients with systemic lupus erythematosus. J. Clin. Invest. 45: 1732-1740.

2. Davis, G. L., Jr., and J. S. Davis, IV. 1973. Detection of circulating DNA by counterimmunoelectrophoresis (CIE). Arthritis Rheum. 16: 52-58.

3. Rochnis, P. G., H. Palefsky, M. Becker, H. Roth, and N. J. Zvaifler. 1974. Native DNA binding in rheumatic arthritis. Ann. Rheum. Dis. 33: 357-360.
4. Hasselbacher, P., and E. C. LeRoy. 1974. Serum DNA binding activity in healthy subjects and in rheumatic disease. Arthritis Rheum. 17: 63-71.

5. Kaznacheev, V. P., and I. V. Poliakov. 1967. A study of some indices of nuclein metabolism in patients with atherosclerosis [in Russian]. Kardiologiya. 7: 22-25.

6. Kamm, R. C., and A. G. Smith. 1972. Nucleic acid concentrations in normal human plasma. Clin. Chem. 18: 519-522.

7. Mandel, P., and P. Metais. 1947. Les acides nucléiques du plasma sanguin chez l'homme. C. R. Hebd. Seances Acad. Sci. 112: 241-243.

8. Barnett, E. V. 1968. Detection of nuclear antigens (DNA) in normal and pathologic human fluids by quantitative complement fixation. Arthritis Rheum. 11: 407-417.

9. Yamashita, T., and M. Yamada. 1952. Nucleic acid in serum. Chem. Abstracts. 46: 10362b.

10. Marmur, J. 1961. Procedure for the isolation of deoxyribonucleic acid from micro-organisms. J. Mol. Biol. 3: 208-218.

11. Giles, K. W., and A. Myers. 1965. An improved diphenylamine method for the estimation of deoxyribonucleic acid. Nature (Lond.). 206: 93.

12. Snedecor, G. W., and W. G. Cochran. 1967. Statistical Methods. Iowa State University Press, Ames, Iowa. 91-134.

13 Steinman, C. R. 1975. Use of nucleic acid hybridization for specific detection of submicrogram quantities of DNA and its application to human plasma. Clin. Chem. $21: 407-411$.

14. Reich, P. R., P. H. Black, and S. M. Weissman. 1966. Nucleic acid studies of SV40 virus-transformed and normal hamster cells. Proc. Natl. Acad. Sci. U. S. A. 56: 78-85.

15. Hughes, G. R. V., S. A. Cohen, R. W. Lightfoot, Jr., J. I. Meltzer, and C. L. Christian. 1971. The release of DNA into serum and synovial fluid. Arthritis Rheum. $14: 259-266$

16. Harbeck, R. J., E. J. Bardana, P. F. Kohler, and R. I. Carr. 1973. DNA : anti-DNA complexes: their detection in systemic lupus erythematosus sera. J. Clin. Invest. 52 : 789-795.

17. Pincus, T., P. H. Schur, J. Rose, J. L. Decker, and N. Talal. 1969. Measurement of serum DNA-binding activity in systemic lupus erythematosus. N. Engl. J. Med. 281 : 701-705. 